\title{
Preservation of rhizobia by lyophilization with trehalose ${ }^{(1)}$
}

\author{
Pedro Antonio Arraes Pereira( ${ }^{(2)}$, Ann Oliver ${ }^{(3)}$, Fredrick Allen Bliss ${ }^{(4)}$, Lois Crowe $^{(3)}$ and John Crowe $^{(3)}$
}

\begin{abstract}
The objective of this study was to determine if trehalose can effectively enhance the viability and storage lifetime of Rhizobium tropici and Rhizobium etli after lyophilization as compared to the traditional protective combination of sucrose and peptone. Two strains of bean-nodulating rhizobia were effectively preserved in the lyophilized state by $100 \mathrm{mM}$ trehalose, and survived for at least 12 days, even when stored under non-ideal conditions. Trehalose provided better protection than the sucrose/peptone combination. When protective excipients were introduced inside the cells, strain CFN 42 was more sensitive to the type of additive used than strain CIAT 899, probably because CIAT 899 produces $\beta$ (1-2) glucan, which may have a protective effect. $\beta$ (1-2) glucan combined with sucrose protected better than trehalose against leakage from freeze-dried liposomes, but by itself it had no protective capability. There was a high level of unfrozen water associated with the hydrated glucan, in addition to a thermal event at approximately $70^{\circ} \mathrm{C}$, corresponding to an observed gel-sol transition in the glucan. These findings may shed light on the mechanism by which the glucan contributes to the protection of dried cells and liposomes, and may lead to further improvements in rhizobial inoculants.
\end{abstract}

Index terms: storage, inoculation, symbiosis, glucan.

\section{Preservação de rizóbio por liofilização com trealose}

Resumo - O objetivo deste estudo foi determinar se a trealose pode aumentar a viabilidade e o tempo de preservação de estirpes de Rhizobium tropici e Rhizobium etli após a liofilização, comparada com a proteção proporcionada pela combinação tradicional de sacarose e peptona. Duas estirpes de rizóbio para feijão foram preservadas liofilizadas com $100 \mathrm{mM}$ de trealose e sobreviveram por pelo menos 12 dias, mesmo quando armazenadas sob condições não-ideais. A trealose proporcionou uma proteção superior à combinação de sacarose peptona. Quando agentes protetores foram introduzidos dentro da célula, a estirpe CFN 42 foi mais sensível em relação ao tipo de agente usado do que a estirpe CIAT 899, provavelmente porque a estirpe CIAT 899 produz $\beta$ (1-2) glucano, que parece ter também um efeito protetor. $\beta$ (1-2) glucano combinado com sacarose protege mais os lipossomas liofilizados de perdas do que a trealose. Entretanto, o $\beta$ (1-2) glucano, isoladamente, não tem capacidade de proteção. Foi observado um alto nível de água descongelada associado com o glucano hidratado; além disso, o evento termal foi de, aproximadamente, $70^{\circ} \mathrm{C}$, o que correspondeu à transição gel-sol do glucano. Essas descobertas são importantes para o entendimento dos mecanismos com que o glucano contribui para a proteção de células e lipossomas liofilizados e para aumentar a sobrevivência do rizóbio nos inoculantes.

Termos para indexação: armazenamento, inoculação, simbiose, glucano.

\footnotetext{
(1) Accepted for publication on December 12, 2001.

(2) Embrapa-Centro Nacional de Pesquisa de Arroz e Feijão, Caixa Postal 179, CEP 75375-000 Santo Antônio de Goiás, GO. E-mail: arraes@cnpaf.embrapa.br

(3) University of California, Section of Molecular and Cellular Biology, Briggs Hall, 1 Shields Avenue, Davis CA 95616, USA. E-mail: aeoliver@ucdavis.edu, lmcrowe@ucdavis.edu, jhcrowe@ucdavis.edu

(4) University of California, Pomology Department E-mail: fred.bliss@svseeds.com
}

\section{Introduction}

Symbiotic nitrogen fixation results from the interaction of a legume host with rhizobia, leading to root nodulation of the host plant. As there are several native species of Rhizobium present in the soil, introduced strains must be present in extremely large numbers in order to compete with native rhizobia and have agricultural significance. Thus, one of the 
main problems of the inoculation industry is to keep rhizobial cells viable in large numbers in the inoculant. This is especially important with the recent tendency to shift from peat-based to alternative inoculants containing freeze-dried rhizobia.

Although certain rhizobial strains have been preserved for long-term storage by lyophilization (Somasegaran \& Hoben, 1994), this procedure can cause serious problems, such as the denaturation of sensitive proteins (Hellman \& Cammack, 1983; Carpenter et al., 1987), and cell death for some organisms (Mazur, 1968; MacKensie, 1977). Several types of excipients, such as sugars and other carbohydrates, have been used to alleviate the damage caused by freeze drying (Simione \& Brown, 1991). Recently, the disaccharide trehalose, which accumulates to extremely high levels in several dehydrationtolerant yeast strains, has been used with great success to protect bacteria from lyophilization-induced damage (Israeli et al., 1993; Leslie et al., 1995). Escherichia coli cells freeze dried in $100 \mathrm{mM}$ trehalose showed as high as $75 \%$ survival after rehydration, compared to less than $10 \%$ survival after freeze drying in the absence of added sugar (Leslie et al., 1995).

Based on what is known about stabilization of biomolecules by trehalose in vitro (Carpenter et al., 1987; Crowe et al., 1987; Tsvetkov et al., 1989; Harrigan et al., 1990; Crowe et al., 1996), the protection against drying afforded to the bacteria by trehalose is likely to be due to its effects on proteins and membranes.

Equally important to bacterial survival is the maintenance of cell membranes in the liquid crystalline phase at critical periods during drying and rehydration. When lipid bilayers are dried in the absence of carbohydrates, the gel to liquid crystalline phase transition temperature is elevated by as much as $50-80^{\circ} \mathrm{C}$, thus the membranes will pass through a phase transition as they are rehydrated (Crowe \& Crowe, 1988).

Most carbohydrates can form glasses, and this vitrification is also an important characteristic of trehalose in regard to its protection of bacterial cells during lyophilization. Indeed, vitrification has been shown to be necessary but not sufficient for the preservation of liposomes during freeze drying (Crowe et al., 1994). The glass transition temperature $\left(T_{g}\right)$ of trehalose is higher than that of sucrose, enabling it to remain vitrified at higher temperatures than sucrose (Crowe et al., 1994; Oliver et al., 1996). This is the likely explanation for the finding that trehalose protects membranes and intact cells better than sucrose during and after drying, although the two disaccharides are similar in most other aspects (Crowe et al., 1996).

Two rhizobial species which establish an effective symbiosis with the common bean (Phaseolus vulgaris L.) were redefined as Rhizobium tropici (Martinez-Romero et al., 1991) and Rhizobium etli (Segovia et al., 1993).

The objective of this study was to determine if trehalose can effectively enhance the viability and storage lifetime of Rhizobium tropici and $R$. etli after lyophilization, as compared to the traditional protective combination of sucrose and peptone.

\section{Material and Methods}

Rhizobium tropici, strain CIAT 899, and Rhizobium etli, strain CFN 42, were grown in YEM broth with shaking at $28^{\circ} \mathrm{C}$ for 72 hours. The number of cells was quantified, and values of $3.2 \times 10^{11}$ and $2.0 \times 10^{11}$ per $\mathrm{mL}$ were obtained for strains CIAT 899 and CFN 42, respectively. Cell suspensions were centrifuged in Eppendorf tubes and cell pellets were resuspended in a solution of $100 \mathrm{mM}$ trehalose or $7 \%$ peptone $(\mathrm{w} / \mathrm{v})$ containing $7 \%(\mathrm{w} / \mathrm{v})$ sucrose. In order to isolate the $\beta$ (1-2) glucan produced by the CIAT 899 strain, colonies were grown on YEM medium plates at $28^{\circ} \mathrm{C}$ for seven days. $\beta$ (1-2) glucan was extracted by scratching the plates with a spatula to remove the bacterial colonies, and suspending them in sterile water. The dissolved $\beta(1-2)$ glucan was separated from the bacterial cellular residue by filtering through an $0.2 \mu \mathrm{m}$ pore Millipore filter, freeze dried, and quantitated.

A Perkin Elmer Fourier transform infrared (FTIR) spectrometer 1750 optical bench was used to study the gel to liquid crystalline phase transition temperature $\left(\mathrm{T}_{\mathrm{m}}\right)$ of the bacterial membranes, as previously described (Crowe et al., 1989). Briefly, samples were sandwiched between two $\mathrm{CaF}_{2}$ windows and loaded onto a temperature-controlled holder. Temperature of the samples was regulated with a Peltier device designed by Paige Electronics (Davis, CA). Samples were scanned in the range of $3,000-1,000 \mathrm{~cm}^{-1}$ and examined in the range of $2,900-2,800 \mathrm{~cm}^{-1}$, for the symmetric $\mathrm{CH}_{2}$ stretch, which shifts by approximately $3 \mathrm{~cm}^{-1}$ as the lipid is chilled through its phase transition.

Trehalose and other excipients were introduced into the bacterial cells by passing the cells through their gel to 
liquid crystalline phase transition temperature in the presence of a relatively high external solute concentration $(100 \mathrm{mM}$ trehalose, or sucrose + peptone, both at $7 \% \mathrm{w} / \mathrm{v})$. Under these conditions, solute will pass into the cells and reduce its concentration gradient, as the cell membranes become transiently leaky (Leslie et al., 1995; Beattie et al., 1997). Cell suspensions $(500 \mu \mathrm{L})$ were placed into $1.5 \mathrm{~mL}$ Eppendorf tubes and capped (samples used in lyophilization studies were capped with perforated caps). The tubes were placed in racks inside a Cryomed Regulated Cooling System 910 with a Model 1010 Microcomputer (Custom Biogenics Systems, Shelby Township, MI) and chilled through the bacterial cell membrane phase transition (from $22^{\circ} \mathrm{C}$ to $-5^{\circ} \mathrm{C}$ ) at a rate of $5^{\circ} \mathrm{C} / \mathrm{min}$.

Once below $\mathrm{T}_{\mathrm{m}}$, cell suspensions were chilled with the Cryomed freezer at a rate of $99^{\circ} \mathrm{C} / \mathrm{min}$ to a temperature of $-80^{\circ} \mathrm{C}$. Frozen cells were transferred to a Virtis Freezemobile 25SL freeze dryer (Gardiner, NY), which has a condenser temperature of $-50^{\circ} \mathrm{C}$ and a vacuum of $10 \mathrm{mTorr}$. Lyophilization was allowed to continue for at least 18 hours, at which point residual water content was about $0.02 \mathrm{~g}$ water/g dry weight.

The freeze-dried cells were rehydrated at room temperature $\left(22^{\circ} \mathrm{C}\right)$ with sterile water in a tissue culture hood, prior to plating on YEM broth medium for colony counts. Alternatively, the Eppendorf tubes containing the freeze dried cells were placed into incubators at 4,30 , or $40^{\circ} \mathrm{C}$ and partially rehydrated during storage in a sealed chamber over a saturated $\mathrm{NaBr}$ solution $(58 \%$ relative humidity at $22^{\circ} \mathrm{C}$ ) (Weast, 1984). After 280 hours of incubation, three samples were taken from each temperature to determine cell survival. The number of colonies was analyzed after log transformation in a completely randomized design.

Egg phosphatidylcholine (EPC, from Avanti Polar Lipids, Alabaster, AL) large unilamellar vesicles (LUVs) were prepared by extrusion in the presence of $100 \mathrm{mM}$ carboxyfluorescein (CF) as previously described. External $\mathrm{CF}$ was removed by passing the liposome sample over a Sephadex G 50-80 column (1x20 cm). Trehalose, sucrose, or $\beta$ (1-2) glucan was added to the liposome suspension at a concentration of $2 \mathrm{~g} / \mathrm{g}$ lipid. Liposome samples $(50 \mu \mathrm{L})$ were placed into Eppendorf tubes with perforated caps, frozen in liquid nitrogen, and transferred directly to the Virtis lyophilizer for at least 18 hours. After lyophilization and rehydration with water, a small volume of LUVs $(5 \mu \mathrm{L})$ was transferred to a cuvette containing $3 \mathrm{~mL}$ water. Samples were excited at $460 \mathrm{~nm}$, and emission was measured at $550 \mathrm{~nm}$ on a Perkin Elmer LS-5 fluorescence spectrophotometer. Intravesicular CF concentrations are selfquenching, so the emission at $550 \mathrm{~nm}$ was due only to external CF. Percent leakage was calculated after adding $50 \mu \mathrm{L}$ of $1 \%$ Triton X-100 to each sample to cause total $(100 \%)$ leakage. Percent retention was calculated as the difference between 100 and the measured percent leakage.

The glass transition temperature $\left(\mathrm{T}_{\mathrm{g}}\right)$ of the carbohydrates at different levels of hydration was measured with a high sensitivity differential scanning calorimeter (DSC-7) from Perkin-Elmer, cooled by a liquid nitrogen reservoir. Carbohydrate samples (5 $\mathrm{mg}$ approximately) were dried using small aluminum pans in a dry box maintained at $0 \%$ relative humidity $(\mathrm{RH})$ for several days and stored overnight under vacuum. The pans were either pressure sealed inside the dry box or transferred to RH chambers, maintained at specific relative humidities over saturated salt solutions, for 24 hours before sealing (Weast, 1984). The DSC-7 head was flushed with $\mathrm{He}$, and the box with dry $\mathrm{N}_{2}$. Carbohydrate samples were scanned between $-180^{\circ} \mathrm{C}$ and $200^{\circ} \mathrm{C}$ at $20-50^{\circ} \mathrm{C} /$ minute. Sample pans were weighed on a Cahn C-33 electrobalance before and after DSC scanning to ensure that no water was lost during the procedure. Sample pans were punctured and incubated at $120^{\circ} \mathrm{C}$ for at least 24 hours and re-weighed. This incubation and re-weighing step was repeated until sample weight remained constant for two consecutive days, allowing accurate calculation of sample hydration during the DSC scan.

The unfrozen water fraction was calculated from DSC scans of frozen hydrated glucan samples. The enthalpy of ice melting in the frozen glucan samples was calculated by integrating the area under the ice-melting endotherm. Since the enthalpy of ice melting is known to be $333.88 \mathrm{~J} / \mathrm{g}$ (Weast, 1984), the percentage of total water present in the form of ice can be estimated by dividing the experimentally obtained enthalpy of ice melting by 333.88 . The remainder is the amount of water present in the unfrozen state, which is reported as $\mathrm{g}$ water/g carbohydrate dry weight.

\section{Results and Discussion}

FTIR spectroscopy was used to determine the gel to liquid crystalline phase transition temperatures of the membranes of rhizobial strains CIAT 899 and CFN 42. The mid-point of the transition $\left(\mathrm{T}_{\mathrm{m}}\right)$ was centered at $2^{\circ} \mathrm{C}$ for CFN 42 (Figure 1). Similar results were obtained for strain CIAT $899\left(0^{\circ} \mathrm{C}\right)$. This is not unusual, as Escherichia coli also has a $\mathrm{T}_{\mathrm{m}}$ of $0^{\circ} \mathrm{C}$. However, variability in membrane composition among bacterial species can lead to differences in $T_{m}$, as evidenced by Bacillus thuringiensis, which has a $\mathrm{T}_{\mathrm{m}}$ centered on $12^{\circ} \mathrm{C}$ (Leslie et al., 1995). 
When rhizobial cells were freeze-dried in the absence of added sugar, the phase transition temperature was elevated to $47^{\circ} \mathrm{C}$ (Figure 1). If trehalose (at $2 \mathrm{~g} / \mathrm{g}$ dry weight) was included before freeze-drying, however, the $\mathrm{T}_{\mathrm{m}}$ remained low $\left(9^{\circ} \mathrm{C}\right)$, an effect that protects the membrane from passing through a phase transition upon rehydration (Harrigan et al., 1990).

Knowledge of the membrane $\mathrm{T}_{\mathrm{m}}$ allowed introduction of protective additives to the cytosol of the bacterial cells. In the presence of $100 \mathrm{mM}$ trehalose, cell suspensions were chilled slowly through their phase transition $\left(5^{\circ} \mathrm{C} / \mathrm{min}\right.$ from 20 to $\left.-5^{\circ} \mathrm{C}\right)$. This procedure leads to an equilibration of excipient across cell membranes as shown previously by using ${ }^{14} \mathrm{C}$ trehalose $[10,28]$. This procedure was used to load rhizobial cells with either $100 \mathrm{mM}$ trehalose or the combination of sucrose and peptone, both at $7 \%(\mathrm{w} / \mathrm{v})$.

Trehalose was compared with the combination of sucrose and peptone for its ability to preserve rhizobia cells during lyophilization. Separate suspensions of CIAT 899 and CFN 42 cells were freeze-dried in the presence of either trehalose or sucrose and peptone. CFN 42 cells were more sensitive than CIAT 899 cells to the type of excipient used (Figure 2). CFN 42

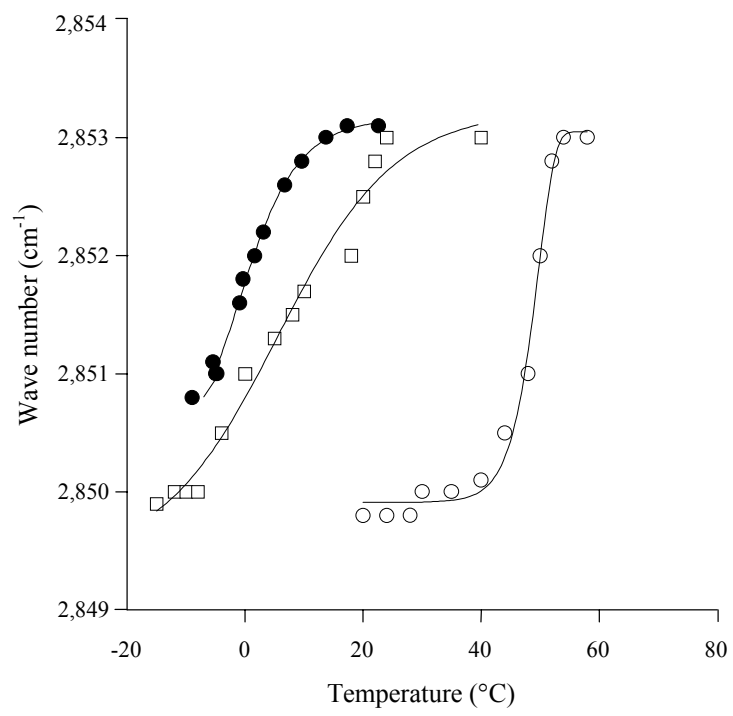

Figure 1. Gel to liquid crystalline phase transitions $\left(T_{m} s\right)$ in rhizobial cells (strain CFN 42), as measured by FTIR. $\mathrm{T}_{\mathrm{m}}$ for cells dried without added sugar (O) was $47^{\circ} \mathrm{C}$, whereas $\mathrm{T}_{\mathrm{m}} \mathrm{s}$ for hydrated cells $(\bigcirc)$ and cells dried with trehalose $(\square)$, were $2^{\circ} \mathrm{C}$ and $9^{\circ} \mathrm{C}$, respectively. cells showed a significant decrease in survival when they were lyophilized in the sucrose/peptone combination but this was not evident when the cells were lyophilized with trehalose. CIAT 899 cells, in contrast, were preserved by either additive.

CIAT 899 and CFN 42 cells lyophilized with either sucrose/peptone or trehalose were stored for 280 hours at temperatures of 4,30 , or $40^{\circ} \mathrm{C}$ in a sealed chamber over a saturated $\mathrm{NaBr}$ solution. In all cases, percent survival decreased as the storage temperature increased (Figure 3). Trehalose provided a greater degree of protection to the lyophilized cells than the sucrose/peptone combination, as survival was higher in all cases when the cells were freezedried in the presence of trehalose. CIAT 899 cells were much less sensitive to the type of excipient used than CFN 42 cells. Similar to the case of survival immediately following lyophilization. This is clear from the results that there was only a slight difference in survival between CIAT 899 cells preserved in trehalose versus sucrose/peptone. In con-

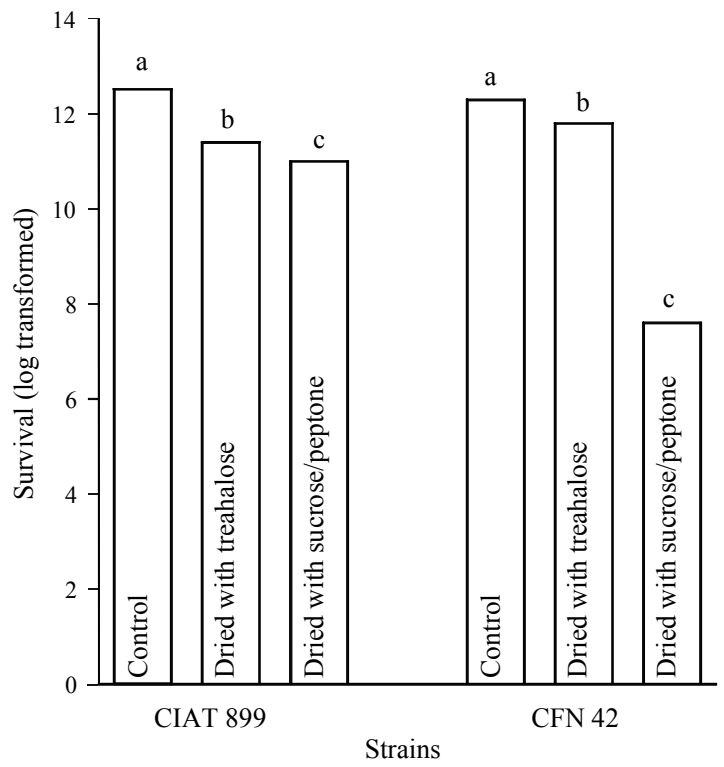

Figure 2. Effect of freeze-drying on the cell survival (log of viable cells $/ \mathrm{mL}$ ) of two Rhizobium strains treated with either $100 \mathrm{mM}$ sucrose $+7 \%(\mathrm{w} / \mathrm{v})$ peptone or $100 \mathrm{mM}$ trehalose, as compared to the non-lyophilized control grown in YEM medium. Mean separations for each rhizobia strains by LSD at 5\% probability level. 
trast, there was a significant difference between the survival of CFN 42 cells depending upon whether they were preserved with trehalose or the sucrose/ peptone combination, especially at higher temperatures.

The disparity between CIAT 899 and CFN 42 in sensitivity to preservative may be partly explained by earlier evidence indicating Rhizobium tropici is relatively resistant to environmental stresses, such as high temperature and field acidity (Hungria et al., 1993; Graham et al., 1994). One explanation may be that this bacterial strain produces a large amount of $\beta$ (1-2) glucan, which has been suggested to have its own protective capability (Hungria et al., 1993; Graham et al., 1994).

In order to examine the role of the secreted $\beta(1-2)$ glucan in the protection of the lyophilized CIAT 899 cells, several carbohydrates were tested, alone and in combination, for their effectiveness in protecting phospholipid vesicles from leaking after lyophilization, storage, and rehydration.

Trehalose was much more effective than sucrose in protecting the freeze-dried liposomes during storage under these conditions (Figure 4). Also, for both trehalose and sucrose, the liposomes leaked more carboxyfluorescein when incubated at the higher

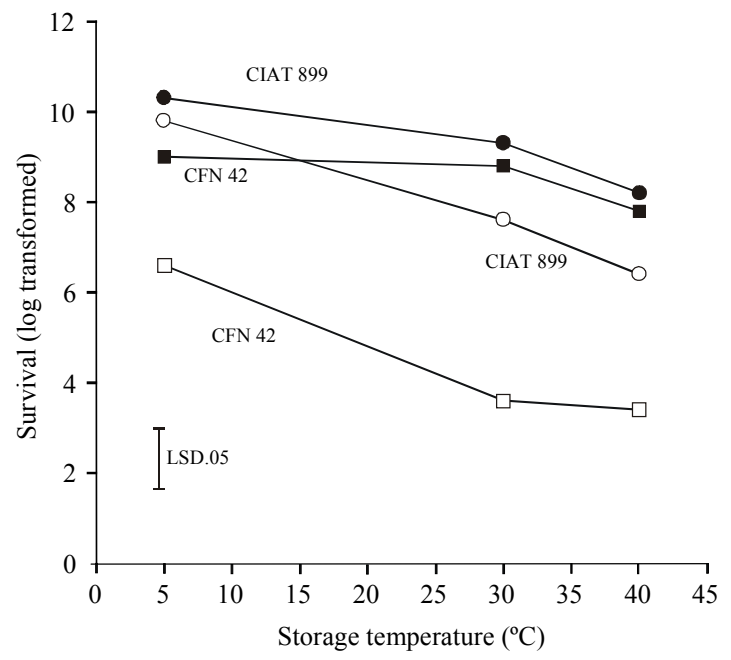

Figure 3. Effect of sucrose/peptone mixture $(\square ; \bigcirc)$ and trehalose $(\square ; 0)$ on survival (log of viable cells $/ \mathrm{mL}$ ) of two rhizobial strains freeze-dried, stored over a saturated solution of $\mathrm{NaBr}$ and incubated at 4,30 , or $40^{\circ} \mathrm{C}$ for 280 hours. temperature. Both these effects are possible due to the relationship between carbohydrate vitrification and liposome preservation. Once the protective carbohydrate is no longer in the vitrified state $\left(T>T_{g}\right)$, the liposomes fuse and leak their contents. This explains why the samples stored at the highest temperature showed lower retention, and also why the liposomes preserved with trehalose had higher retention than those preserved with sucrose $\left(\mathrm{T}_{\mathrm{g}}\right.$ for trehalose $>>T_{g}$ for sucrose) (Crowe et al., 1996). Furthermore, the $T_{g}$ for a given carbohydrate glass drops dramatically as water is added (Roos \& Karel, 1991), which helps to explain the precipitous drop in retention as the liposome samples adsorbed water.

The most striking result however, is that when sucrose and the $\beta(1-2)$ glucan were used in combination, the retention values at $40^{\circ} \mathrm{C}$ were as high as those obtained with trehalose at $22^{\circ} \mathrm{C}$ (Figure 4). The glucan increased the retention of liposomes preserved with sucrose, and stored at $40^{\circ} \mathrm{C}$ for eight

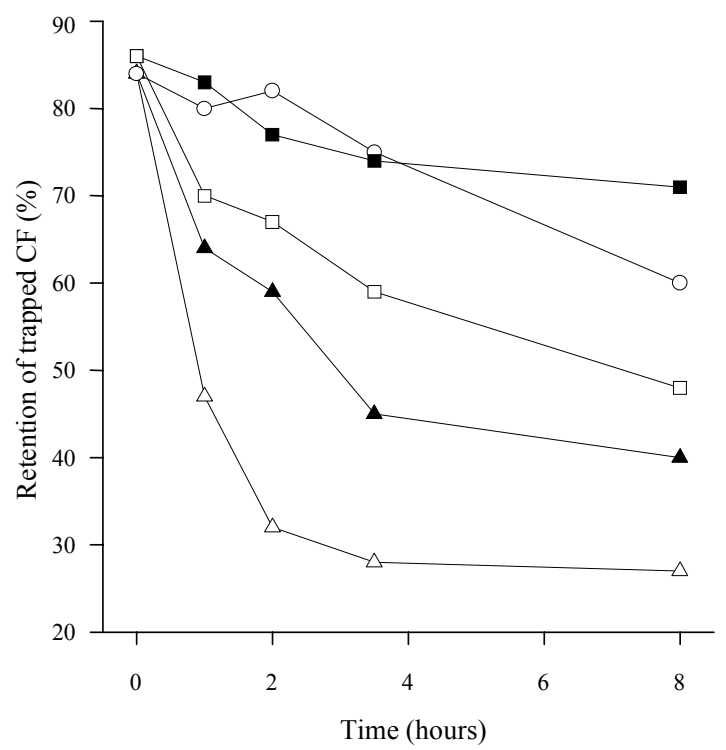

Figure 4. Retention of carboxyfluorescein by egg phosphatidylcholine liposomes after freeze-drying in the presence of various carbohydrates and storage at different temperatures ( $\square$ :trehalose, $20^{\circ} \mathrm{C}$; O:sucrose + glucan, $40^{\circ} \mathrm{C}$; $\square$ : trehalose, $40^{\circ} \mathrm{C} ; \Delta$ : sucrose, $22^{\circ} \mathrm{C} ; \triangle$ :sucrose, $40^{\circ} \mathrm{C}$ ) in a sealed chamber over a saturated $\mathrm{NaBr}$ solution. All additives were present at a concentration of $2 \mathrm{~g} / \mathrm{g}$ lipid before drying. 
hours, from $25 \%$ to $75 \%$. Therefore, glucan caused a three-fold increase in the level of protection afforded by sucrose, although, the $\beta$ (1-2) glucan by itself is not at all protective.

The glucan isolated from CIAT 899 cells provided no protection to the lyophilized liposomes (Figure 3). This result was similar to that found for the monosaccharide glucose (Crowe et al., 1997). However when glucose and the glucan were used in combination, there was some protection from damage, as seen by the $44 \%$ retention value. This result suggests that glucose and the $\beta$ (1-2) glucan might contribute differently to membrane protection, and that when both are present in the correct ratio, retention values are increased.

Both trehalose and sucrose alone or in combination with the glucan, provided excellent protection against lyophilization-induced damage (Figure 5). Retention values reached the $80 \%$ range in both cases when the disaccharide concentration reached about $10 \mathrm{~g}$ additive/g lipid. In fact, in the absence of

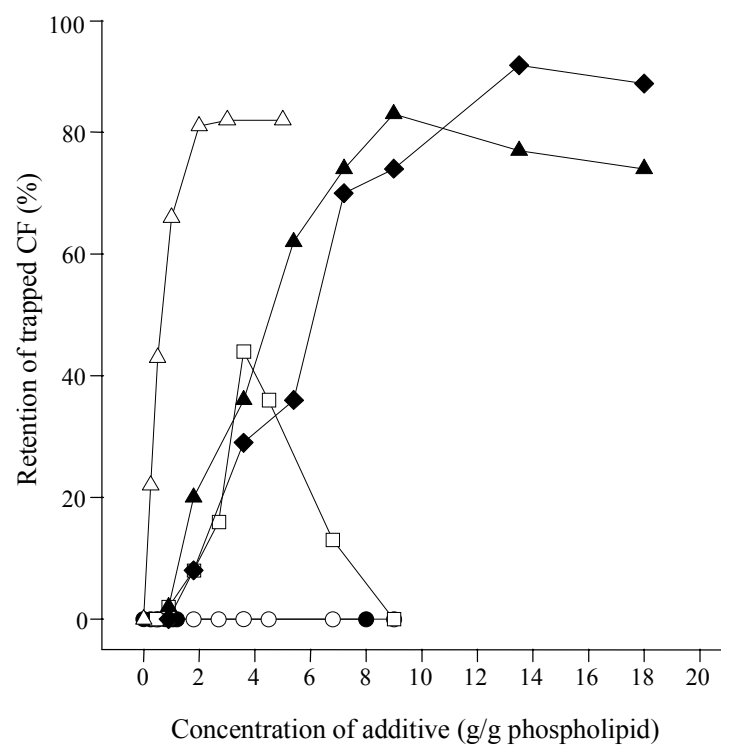

Figure 5. Dose response effect of various sugars (๑) glucan; O: glucose; $\square$ : glucose +1.2 g glucan/g phospholipid; $\boldsymbol{\Delta}$ : sucrose $+1.2 \mathrm{~g}$ glucan $/ \mathrm{g}$ phospholipid; $\checkmark$ : trehalose $+1.2 \mathrm{~g}$ glucan $/ \mathrm{g}$ phospholipid; $\triangle$ : trehalose) on carboxyfluorescein retention by freeze-dried liposomes. Samples were rehydrated and measured immediately after removal from the lyophilizer. the glucan, liposomes preserved with either trehalose or sucrose can show retention values in the $80 \%$ range with as little as $2 \mathrm{~g}$ additive/g lipid.

At either extreme of the glucan to glucose spectrum (either $100 \%$ glucan or $100 \%$ glucose), CF retention was $0 \%$ (Figure 6). There was a range in the middle with a peak at a glucose weight fraction of 0.75 , in which a significant percentage of carboxyfluorescein was retained by the liposomes (44\%). As mentioned before, this finding suggests that glucose and the glucan might each make a specific contribution to membrane stabilization, but that neither one is capable of preserving membrane integrity by itself. Thus, when the glucan is present at high concentrations, glucose cannot gain access to the membrane, and vice versa. The membrane is only protected, therefore, when the two carbohydrates are present in the correct ratio.

In order to determine if the contribution of the $\beta(1-2)$ glucan to protection of the liposomes and bacteria was due to its formation of a high-melting glass, DSC was used to measure glass transitions in carbohydrate samples of many different hydration levels over a broad temperature range. Most long

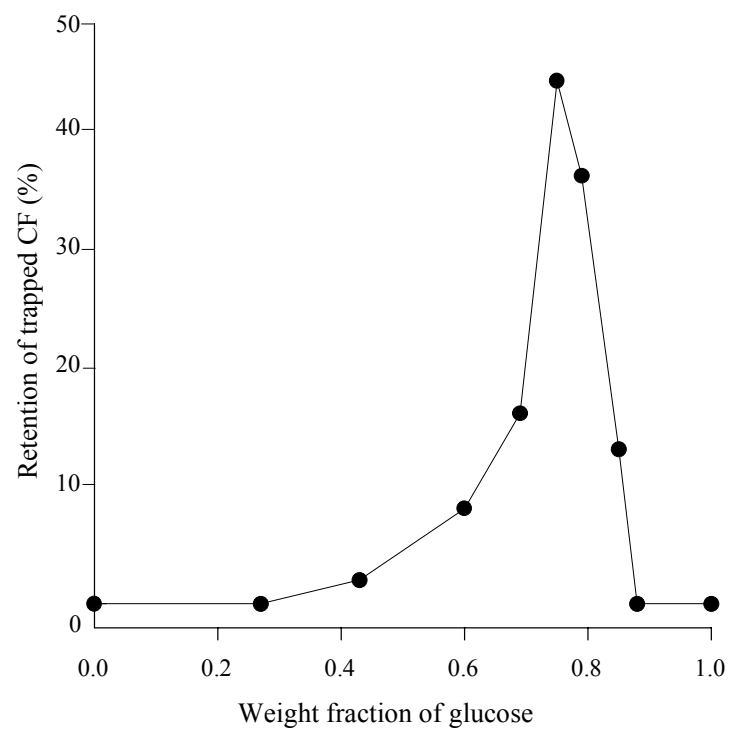

Figure 6. Retention of carboxyfluorescein by liposomes freeze-dried in the presence of various combinations of glucose and $\beta$ (1-2) glucan $(0.0=100 \%$ of glucan; $1.0=100 \%$ of glucose) . 
chain carbohydrates have $T_{g}$ values of about $200^{\circ} \mathrm{C}$ under anhydrous conditions (Slade \& Levine, 1995). However, in thermal scans between -100 and $150^{\circ} \mathrm{C}$, no glass transition was found in dry glucan samples, which decomposed at temperatures below $150^{\circ} \mathrm{C}$. Therefore, vitrification is unlikely to be the mechanism by which the glucan protects liposomes and bacteria during freeze-drying. The DSC scans in hydrated glucan samples also gave unexpected results. Figure 5 shows a temperature scan of a hydrated glucan sample between -50 and $100^{\circ} \mathrm{C}$. No glass transition is evident, providing further evidence that vitrification of the glucan is not involved in its effects on stability of the rhizobial cells and liposomes in the dry state. However, a thermal event is clearly discernible at $73^{\circ} \mathrm{C}$ in the fully hydrated glucan. This value is outside a reasonable temperature range for a glass transition in a hydrated sample, even for a polymer (Slade \& Levine, 1995). Nevertheless, these high temperature transitions were quite repeatable, so the possibility that they might provide some information about the mechanism of protection was explored.

Another striking result from the DSC work was the amount of water associated with fully hydrated glucan samples. A value of $3.1 \mathrm{~g}$ unfrozen water $/ \mathrm{g}$ dry weight $( \pm 0.4 \mathrm{~g} / \mathrm{g} ; \mathrm{n}=4)$ was calculated, which is several-fold greater than that seen in common carbohydrates. Trehalose and sucrose, for example, have values of only 0.56 and $0.20 \mathrm{~g} / \mathrm{g}$, respectively (Levine $\&$ Slade, 1988). This ability of the glucan to absorb water was evident in its physical character as well, as it forms a gel in the fully hydrated state.

Thus, it was hypothesized that the thermal events seen in DSC scans of hydrated glucan in the range of $70^{\circ} \mathrm{C}$ might be gel-sol transitions in this highly hydrated polymer (Figure 7). This possibility was investigated in the following way. A droplet of the hydrated gel was transferred to a $1 \mathrm{~mm}$ diameter $\mathrm{x}$ $4 \mathrm{~cm}$ capillary tube, occupying about $2 \mathrm{~mm}$ of the length of the tube. A thermocouple was threaded into the droplet, after which the tube was sealed with Critoseal putty and then heated over a hot water bath. Visual observation of the glucan showed abrupt melting of the gel at $65-75^{\circ} \mathrm{C}$ in four samples, indicating that the thermal event seen in DSC, also between $65-75^{\circ} \mathrm{C}\left(0=69.6 \pm 4.2^{\circ} \mathrm{C}, \mathrm{n}=7\right)$, is likely to be this gelsol transition.

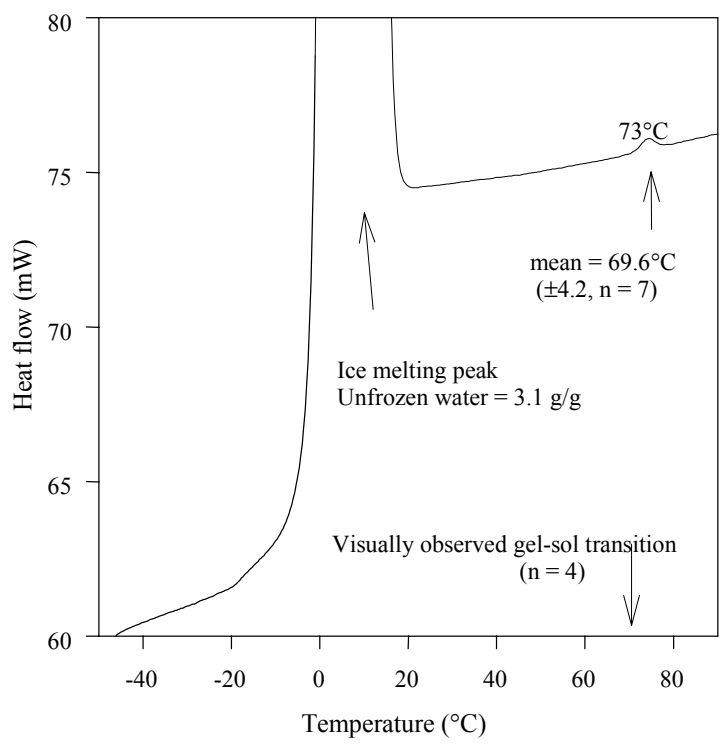

Figure 7. Differential scanning calorimetry spectrum of hydrated $\beta$ (1-2) glucan. The trace shows a dialyzed glucan sample, in which no glass transition temperature is apparent. The large endotherm, with an onset of $0^{\circ} \mathrm{C}$, is the icemelting peak. The unfrozen water associated with the glucan was calculated from these peaks as $3.1 \mathrm{~g}$ water/g dry weight $( \pm 0.4 \mathrm{~g} / \mathrm{g}, \mathrm{n}=4)$.

The $\beta$ (1-2) glucan may be instrumental in stabilizing dry samples, therefore, not because of its glass forming properties, but because of its ability to form this hydrated gel. It was hypothesized that the glucan adsorbs water from the vapor phase preferentially, preventing lipids and other carbohydrates present from becoming hydrated. Trehalose is an example of a carbohydrate that can act in this manner. Initially, as moisture is added to dry glasses formed from trehalose and liposomes, a portion of the sugar forms trehalose dihydrate (Crowe et al., 1996). The result is that the water is effectively sequestered away from the glass, and the $\mathrm{T}_{\mathrm{g}}$ of the glass remains high (Crowe et al., 1996).

\section{Conclusions}

1. CFN 42 cells show a significant decrease in survival when they are lyophilized in sucrose/peptone combination in comparison with cell lyophilized with trehalose. 
2. The rhizobial strain CIAT 899 is preserved by sucrose/peptone as well as by trehalose.

3 . The $\beta(1-2)$ glucan abundantly produced by strain CIAT 899 has a strong affinity for water, as evidenced by the large amount of unfrozen water associated with the glucan; this characteristic, which leads to gel formation in fully hydrated samples, may partially explain its protective properties.

\section{Acknowledgements}

To the National Science Foundation for the IBN 93-08581 grant and to the Office of Naval Research, for the USN N00014-94-1 grant.

\section{References}

BEATTIE, G. M.; CROWE, J. H.; LOPEZ, A. D.; RICORDI, C.; HAYEK, A. Trehalose: a cryoprotectant that enhances recovery and preserves function of human pancreatic islets after long-term storage. Diabetes, New York, v. 46, p. 519-523, 1997.

CARPENTER, J. F.; CROWE, L. M.; CROWE, J. H. Stabilization of phosphofructokinase with sugars during freeze-drying: characterization of enhanced protection in the presence of divalent cations. Biochimica et Biophysica Acta, Amsterdam, v. 923, p. 109-115, 1987.

CROWE, J. H.; CROWE, L. M. Factors affecting the stability of dry liposomes. Biochimica et Biophysica Acta, Amsterdam, v. 939, p. 327-334, 1988.

CROWE, J. H.; CROWE, L. M.; CARPENTER, J. F.; WISTROM, C. A. Stabilization of dry phospholipid bilayers and proteins by sugars. Biochemical Journal, London, v. 242, p. 1-10, 1987.

CROWE, J. H.; HOEKSTRA, F. A.; CROWE, L. M.; ANCHORDOGUY, T. J.; DROBNIS, E. Lipid phase transitions measured in intact cells with Fourier transform infrared spectroscopy. Cryobiology, New York, v. 26, p. 76-84, 1989.

CROWE, J. H.; LESLIE, S. B.; CROWE, L. M. Is vitrification sufficient to preserve liposomes during freeze-drying? Cryobiology, New York, v. 31, p. 355-366, 1994.

CROWE, J. H.; OLIVER, A. E.; HOEKSTRA, F. A.; CROWE, L. M. Stabilization of dry membranes by mixtures of hydroxyethyl starch and glucose: the role of vitrification. Cryobiology, New York, v. 35, p. 20-30, 1997.
CROWE, L. M.; REID, D. S.; CROWE, J. H. Is trehalose special for preserving dry biomaterials? Biophysical Journal, New York, v. 71, p. 2087-2093, 1996.

GRAHAM, P. H.; DRAEGER, K. J.; FERREY, M. L.; CONROY, M. J.; HAMMER, B. E.; MARTINEZ, E.; AARONS, S. R.; QUINTO, C. Acid pH tolerance in strains of Rhizobium and Bradyrhizobium, and initial studies on the basis for acid tolerance of Rhizobium tropici UMR1899. Canadian Journal of Microbiology, Ottawa, v. 40, p. 198-207, 1994.

HARRIGAN, P. R.; MADDEN, T. D.; CULLIS, P. R. Protection of liposomes during dehydration or freezing. Chemistry and Physics of Lipids, Amsterdam, v. 52, p. 139-149, 1990.

HELLMAN, K. D. S.; CAMMACK, K. A. The effect of freeze-drying on the quaternary structure of L-asparaginase from Erwinia carotovora. Biochimica et Biophysica Acta, Amsterdam, v. 749, p. 133-142, 1983.

HUNGRIA, M.; FRANCO, A. A.; SPRENT, J. I. New sources of high-temperature tolerant rhizobia for Phaseolus vulgaris L. Plant and Soil, The Hague, v. 149, p. 103109, 1993.

ISRAELI, E.; SHAFFER, B. T.; LIGHTHART, B. Protection of freeze-dried Escherichia coli by trehalose upon exposure to environmental conditions. Cryobiology, New York, v. 30, p. 519-523, 1993.

LESLIE, S. B.; ISRAELI, E.; LIGHTHART, B.; CROWE, J. H.; CROWE, L. M. Trehalose and sucrose protect both membranes and proteins in intact bacteria during drying. Applied and Environmental Microbiology, Washington, v. 61, p. 3592-3597, 1995.

LEVINE, H.; SLADE, L. Principle of acryostabilization and technology from structure/property relationships of carbohydrate/water systems C: a review. Cryo-Letters, Cambridge, England, v. 9, p. 21-63, 1988.

MACKENSIE, A. P. Comparative studies on the freezedrying survival of various bacteria: gram type, suspending media and freezing rate. Developments in Biological Standardization, Basel, v. 36, p. 263-277, 1977.

MARTINEZ-ROMERO, E.; SEGOVIA, L.; MERCANTE, F. M.; FRANCO, A. A.; GRAHAM, P. H.; PARDO, M. A. Rhizobium tropici, a novel species nodulating Phaseolus vulgaris L. beans and Leucaena sp. trees. International Journal of Systematic Bacteriology, Washington, v. 41, p. 417-426, 1991. 
MAZUR, P. Survival of fungi after freezing and desiccation. In: ROSE, A. (Ed.). The fungi. New York: Academic, 1968. p. 325-394.

OLIVER, A. E.; CROWE, L. M.; ARAUJO, P. S. de; FISK, E.; CROWE, J. H. Arbutin inhibits PLA2 in partially hydrated model systems. Biochimica et Biophysica Acta, Amsterdam, v. 1302, p. 69-78, 1996.

ROOS, Y.; KAREL, M. Amorphous state and delayed ice formation in sucrose solutions. International Journal of Food Science and Technology, London, v. 26, p. 553566, 1991.

SEGOVIA, L.; YOUNG, J. P. W.; MARTINEZROMERO, E. Reclassification of American Rhizobium leguminosarum biovar phaseoli type I strains as Rhizobium etli sp. nov. International Journal of Systematic Bacteriology, Washington, v. 43, p. 374-377, 1993.
SIMIONE, F. P.; BROWN, E. M. ATCC preservation methods: freezing and freeze-drying. 2. ed. Rockville: American Type Culture Collection, 1991. 1v.

SLADE, L.; LEVINE, H. Glass transitions and water-food structure interactions. Advances in Food and Nutrition Research, New York, v. 38, p. 103-269, 1995.

SOMASEGARAN, P.; HOBEN, H. J. Handbook for rhizobia methods in legume: Rhizobium technology. New York: Springer, 1994. 450 p.

TSVETKOV, T. D.; TSONEV, L. I.; TSVETKOVA, N. M.; KOYNOVA, R. D.; TENCHOV, G. G. Effect of trehalose on the phase properties of hydrated and lyophilized dipalmitoylphosphatidylcholine multilayers. Cryobiology, New York, v. 26, p. 162-169, 1989.

WEAST, R. C. (Ed.). CRC handbook of chemistry and physics: a ready-reference book of chemical and physical data. 64. ed. Boca Raton: CRC Press, 1984. Irregular pagination. 